\title{
Buddhist Personalities: From Doctrine to Practice in Vietnam during the Period of International Integration
}

\author{
Dr. Le Ngoc Thong* \\ Political Theory faculty, National Economics University, Viet Nam \\ *Corresponding Authors: Dr. Le Ngoc Thong, Political Theory faculty, National Economics University, \\ Viet Nam
}

\begin{abstract}
With an analytical approach to synthesis, logic with history, observations, interviews, etc., the article presents an overview of Buddhist doctrine on personalities content: human life, the concept of liberation and the path of liberation; At the same time, analyzing the process of implementing the Buddhism of Vietnamese Buddhists in the context of international integration. From there draw the necessary conclusions.
\end{abstract}

Keywords: Personalities, Buddhism, Believers, International Integration

\section{SCIENTIFIC BASIS OF THE ARTICLE}

\subsection{Introduction}

Buddhist personalities were nicely spread and deeply influenced the spiritual life of people in Vietnam. Today, in the context of international integration, Buddhism has made great changes, significant impact, both positive and negative, to social life, lifestyle, ethicsof Vietnamese society represented by the Buddhist class.

\subsection{Rationale}

The article is based on the dialectical materialist methodology of philosophy and the history of philosophy, combined with the methodology of studying Oriental philosophy.

\subsection{Specific Research Methods}

Combination of methods: analysis with synthesis, logic with history, observation, interview,...

\section{CONTENT AND RESEARCH RESUltS}

\subsection{Buddhist (PG) Personalities - Systems Philosophy - Religious}

Buddhist personalities is primarily ideological content covers the entire system of Buddhist teachings.

\subsubsection{Buddhist Conception of Human}

Starting point - the theory of causation:

All things phenomena are causal, dependent origination. Things, phenomena caused by the combination of conditions that become and lose when the coast breaks. The cause is the latent power of all the formation, transformation. Dependent conditions are relationships, conditions, influences that help the cause to produce results. All the phenomena are mutually dependent. That is the cause. The theory of cause and condition, in doing "Buddha Self Theory" (sub-set of I p. 291) has said: It will have the other one there, This arising, that arises, This is not the other one does not, this kill the other one killed[1, 95]. In the "Surangama Capital" assertion: actually born nor born, but kill nor destroy. When the causes and conditions meet, it is said that birth, when the coast break, it is said to kill. The "Great Mahaparinirvana" said: all things, phenomena are not self-nature, Because of conditions that are born, because of conditions that are destroyed. Buddhism does not claim that things are not natural, nor are they created by a divine being, but that all things are born of it. The cause and effect concerned, the Buddha generalized the theory of cause and effect. From there, there are two direct consequences: impermanence and selflessness. 
The theory of impermanence (Amicca) is one of the fundamental theories in PG, which is a theoretical basis for the way of life, for the Buddhist philosophy of life. Accordingly, things, phenomena, people always change according to the law: The formation - attachment - destruction - nothing. Creatures follow the rules of birth - attachment - mutation - kill. Anatta: An object of no real nature that is a combination of cause and condition. Figures and figures are composed of parts that can be merged or split.

With the basic principle above, Buddhism presents the problems of human life: Where do people come from? How are humans born? What is human life? Way of liberation for humans. Buddhism identifies man as a cosmic whole, a miniature universe, the result of a combination of fame and beauty with two parts of physiology and psychology. "Meditation" refers to human physiology as a combination of four material elements: earth, water, fire, wind. Human psychology: What is psychology? According to the Buddha, the psyche consists of passions, thoughts, actions, and consciousness.

Human beings are born due to twelve factors of harmony and transformation that become:Ignorance causes the Action,Action causesHealth, HealthcausesConsciousness, Consciousness causes the sphere,sphere causes emotions,emotions causes sensation, sensation causes love,love cause Head,Head causes Image,Image causes birth,Birth cause old age, death.

So, the visible existence of a conscious human is only temporary (Form form-emptiness emptiness) in the continuous cycle of innumerable causes and origins. With this approach, all human activity (karma) is governed by the body, speech, mind and karmic retribution. Man has birth and death, but kamma is created and still works to bring a new composition of the five aggregates for the next life with six paths: sky, humans, Atula, animals, ghosts, hell. It does not stop, like a spinning wheel. Human is a complete organ of body and mind. The "Flower Adornment" said: "Human wins": Human is the most; "When losing body is very difficult to return to human". So, human beings to create good karma, and repentance to change to evil karma. Man is governed by the law of impermanence with the process of birth - old - sick - death. The existence of temporary body as breath. Along the body, passive, thought, action, consciousness also fluctuate non-stop: "Life long a thought". Life and death continue uninterruptedly. From impermanence to the theory of non-self. Man is the result of the temporary union of the five aggregates: form, feeling, perception, volition, consciousness. The Buddha says: "Lust has been made by the self (the four elements), from where is the fall? Form has been created by impermanence; Where are impermanence come from?[5, 159]. According to the "I" often remains, unchanging, so ambitious, trying to cling to Me, with many desires, selfish, not escape the cycle of birth and death. It is the source of ignorance, of samsara, of suffering. The Law of Anatomy, Anatta, contains the dialectical elements of in-depth awareness of movement, of relativity.

\subsubsection{The Concept of Human Life}

According to Buddhist teachings, human life is manifested through the Four Noble Truths, derived from Dukkha Arya Satya: "I speak only suffering and the road to end suffering."[4, 272].

The first truth is "Life is suffering: "Birth is suffering, aging is suffering, illness is suffering, death is suffering, sadness is suffering, boring is suffering, love separates is suffering, desire fails is suffering, the five aggregates are suffering." Suffering both physically and mentally. There, referring to the cause of psycho-physiological, not to mention the social cause should be the way to remove suffering psychological nature.

The second Noble Truth (Dukkha Samudaya Arya Satya). The Buddhist philosophy holds that the cause of suffering is craving from ignorance and delusion. Man is unaware of the nature of this world and even the human body is conditioned by harmony that changes and changes impermanence. People want to survive but reality and life are rotated: Birth - Aging - Disease - Death, non - stop. So people are born false hope, self-ego, selfish, greedy, appropriated, life long suffering. Man is governed by twelve causal factors: Ignorance, Action, Health, Consciousness, sphere, emotions, sensation,love, Head,Image, Birth,Old,Death; They are related and transformed to each other, both as human beings cause and results as of the past - present - future. Want to end of suffering must be cut one of the twelve conditions.

The Third Noble Truth: "Eradication - liberation". 
Buddhism only absorbed a taste, the taste of liberation - The ultimate goal of Buddhism is to liberate human beings from suffering suffering from samsara, reaching Nirvana. "The eradication of greed, the eradication of anger, hatred, has eradicated ignorance (ignorance), which is Nirvana" (A Journey) [1, 86]. Or "Turned down selfishness, then witnessed the realms of Nirvana." Religious dictionary says that "Nirvana is a spiritual world after destroying samsara" [3, 899]. Nirvâna is the world of supertime-space, the peaceful, enlightened and liberating realm of enlightened beings in Buddhism. All beings are capable of becoming Buddhas, being equal in the path of liberation. Buddha said: "I am the Buddha has become, People are the Buddha will be". "Love and need are communication strings between people." There is no level in the bloodstream with the same redness, no class in the salty tear. Every person born is not brought in the neck or necklace in the forehead ... "[9, 115].

The Fourth Noble Truth "Marga Satya" - Path, Way, Method of Salvation.

Buddhism shows 37 methods - the product:

The four foundations of mindfulness, four things, four well, five bases, five forces, seven sense, eight main roads. First of all, we must perform the Three Teachings (Gender - Determination - Wisdom) and practice the Noble Eightfold Path (Righteous Thoughts, Right Thought, Righteous Thoughts, Righteous Thoughts, Righteous Thoughts, Righteous Thoughts, Righteous Thoughts. Geography is the practice of morality, the means of changing the way of thinking, the way of living toward good. To make the mind and body clean; undergoing certain moral transformations of good deeds. To practice the world, to do the right thing - to say the right word: righteousness - to act in a righteous and righteous way - to add to the good that karma itself. Wisdom is knowing, purifying and developing mind. The "Dhammapada" states: "The noble path is the Noble Eightfold Path. The highest truth is the Four Noble Truths. No love is the highest state ... " [2, 173]. Buddhism focuses on catechesis as the cessation of suffering to Nirvana. The path to Nirvana is a process of self-realization, each one performs..

\subsection{Realization of the Buddhist Life in Vietnam during the Period of International Integration}

\subsubsection{History of Buddhism in Vietnam}

Buddhism was introduced in Vietnam from the beginning of the waterway from India and the road from China with all three elements Meditation - Pure - Secret. Zen advocated centralized intelligence to find out the truth of Buddhism: from Zen Vinitaruci to Vo Ngon Thong to send Thao Duong to meditate Truc Lam, the latter still appears some other Zen: Tao Dong, Lien Tong, Lam Te, Lieu Quan, ...).The Pure Land is based on the supernatural power of the Buddha Amitabha to help ordinary people enlighten. The Pure Land teaches the followers of a particular Nirvana - the West. Pure Land Buddhism says that it is only necessary to recite the name of Amitabha Buddha often to the West. Tantrism is the policy of the use of mysterious enlightenment as the use of ghost, mantra, hit ... to quickly reach enlightenment and liberation. Historically, "Pure Land Buddhism and Tantra in Vietnam have not become separate schools, independent of Zen, but only elements that are received by Zen." [9-84, 85]. Vietnamese Buddhism has a close relationship with Vietnamese thought and culture. Thus, on the one hand Buddhism has contributed to Vietnamese culture and on the other hand Vietnamese culture has transformed Buddhism, making Vietnamese Buddhism its own characteristics. Buddhism is a good life, ethical life, honesty, compassion, tolerance, masses of labor received. Professor Tran DinhHuou has general in Vietnam: "... the monk attached to the poor population and the temple associated with the village" [7,58]. Vietnamese Buddhism incorporates the religious life and the life of the nation. Buddhism respects women very much, so there are both male and female Buddha. Besides the Buddha also Quan Yin Buddha, there are many pagodas bearing the name of women, such as Dau Pagoda, Ba Da Pagoda, Ba Tuong Pagoda, Ba Danh Pagoda ...As a political, economic and cultural center of the nation, right from the beginning, Thang Long - Hanoi was an important Buddhist center. Buddhism in Vietnam reached its peak in the era of the Ly - Tran (XI XIV). Tran Zen masters said that the human body is composed of mindfulness, causation, the five aggregates that are produced by the parents, by the four elements, the aggregate of the five aggregates, subject to the laws of extermination (impermanence). ), should be virtual (not self). Human life is fleeting, temporary suffering. The cause of creating suffering is ignorance, perception is ignorance born dream concept. In order to eradicate suffering, first of all, it is not necessary to create karma, to eliminate ignorance, to destroy the self, to realize the impermanent world of selflessness, from which 
the chains of samsara, the brain in the mortal body, to place Nirvana liberation. The way of liberation proposed by the Tran Zen Masters is a combination of enlightenment and enlightenment. Remedial practice by the Three classes and the eight. Awakening by intuition "mind-heart"; with the principle of introspection, centralization and disobedience. Thus, Vietnamese Buddhism in this period was closely associated with the nation and found a new path of enlightenment: saving humanity. Buddhists actively participate in the construction and defense of the country.

Then, Vietnamese Buddhism has its ups and downs. Today, in the process of international integration, the country has a fast and stable growth. Vietnamese Buddhism has made some flourishes. Activities related to belief and religion have been restored and have a considerable impact on the economic, social and cultural life of the country.

\subsection{The Current Status of Buddhist Personalities in Vietnam Today}

Situation operation Buddhist personalities expressed in religious beliefs; practice ritual and canon law.

\subsubsection{The Issue of Religious Belief in Vietnam}

Historically, Vietnam has been leading the doctrine of the doctrines and other religions in their own way, with different ways of influencing the population. In 2010, there were 14,380,000 Buddhists in Vietnam, accounting for $16.4 \%$ of the total population and $2.7 \%$ of the total number of Buddhists in the world, 10 of the top 10 countries with highest Buddhist proportions.

Table1. Countries with the highest proportion of Buddhists, statistics in 2010

\begin{tabular}{|l|l|l|}
\hline \multicolumn{1}{|c|}{ Country } & The number of Buddhists is estimated & Percentage of Buddhists in the population \\
\hline Cambodia & 13.701 .660 & $96,90 \%$ \\
\hline Thailand & 64.419 .840 & $93,20 \%$ \\
\hline Myanmar & 48.415 .960 & $87,90 \%$ \\
\hline Bhutan & 563.000 & $74,70 \%$ \\
\hline Sri Lanka & 14.222 .844 & $70,2 \%$ \\
\hline Laos & 6.092 .000 & $95,00 \%$ \\
\hline Korea & 11.050 .000 & $22 \%$ \\
\hline Japan & 84.653 .000 or 45.807 .480 & $67 \%$ or $36,2 \%^{[6]}$ \\
\hline Singapore & 1.725 .510 & $33,90 \%$ \\
\hline Taiwan & 8.000 .000 or 4.945 .600 & $35 \%$ or $21,1 \%^{[7]}$ \\
\hline Vietnam & 14.380 .000 & $16,4 \%$ \\
\hline
\end{tabular}

(Source: wikipedia.org)

Buddhism today still exists with a full mechanism, sticking with harmony with folk beliefs, so the people of Buddhism have great persuasion towards the people towards the spirit of equality, humanity, advocacy. liberate people. When people practice religious rituals, people have accepted Buddhism as well. Moreover, since the country entered the doimoi period, with the negative side of the market economy, people faced many challenges, so they needed help, "blessing" of the Buddha. power. On the other hand, Vietnam Buddhism with elements of Meditation - Pure - Secret has the ability to meet the needs of the social class, attractive, especially for the common people and the nature of the mass. People at all levels are able to enter the religious life easily. At the same time, Buddhism is also a nourishment. Meditation relaxes the nerves and muscles, concentrates thoughts in one place, rests with the law of impermanence, not self, ... is the effect of causing people to overcome negative emotions, return to the state of peace. normal, or serene, beneficial to life. Many people have accepted and become Buddhists with a great diversity of occupations and ages. In recent years, with the appropriate social policy, the work of Buddhist scriptures and propaganda has made remarkable progress. Periodically, the pagodas held lectures on Buddhist scriptures, the way of practice, performing rituals. Along with the moral life of Buddhist monks, many Buddhist establishments have archives and translations of Vietnamese texts in neat and simple language. The popular books on Buddhism such as "General Buddhist", "Introduction Buddhism", "Buddhist Dharma Regular" ... have been widely edited and published; mass media, and other cultural activities. Since then, today's lay Buddhists have a basic understanding of the Buddhist doctrine. From that came the idea of "doing good, avoiding evil". Religious belief in Vietnamese believers is evident in the belief in samsara, karma, cause and effect, in the direction of the Buddha. The Buddha was the Buddha close. Buddha Thousand Eyes Thousand Hands "ready to witness the sincere thoughts and good work of believers 
and to save humanity. Religious beliefs are also expressed. This religious belief is also reinforced by the sympathy for the monks - living very purely, without regard to ordinary material life, but rich in mercy, tolerance, willing to work charity, giving to the living beings, helping the poor through the tribulation. This belief forms a deep connection, which is the basis for the long-term survival of Buddhism in Vietnam.

\subsubsection{Ritual Practice and Buddhist Canon Law in Vietnam}

\section{a) The Practice of Buddhist Ritual in Vietnam}

The truths, the content of Buddhism must be realized, the religious life of religious practice leading to the transformation of human thought and action to achieve a natural life, cavity. In it, the practice of ritual and Buddhist precepts of believers is an important part of the religious life, expressing a vividly Buddhist life in the present context. It is the liturgy of incense, Buddhist ceremony...

Table2. The main Buddhist ceremony of the year

\begin{tabular}{|c|c|c|}
\hline Seq. & Buddhist ceremony & Lunar calendar date \\
\hline 1 & Buddha's Birthday & $15 / 4$ \\
\hline 2 & Worshiping Buddha attained enlightenment & $08 / 12$ \\
\hline 3 & Vu Lan ceremony & $15 / 7$ \\
\hline 4 & \multicolumn{2}{|c|}{ The first and the full moon day every month } \\
\hline
\end{tabular}

(Source: author)

The faithful can now go to temples for the ceremony or Buddhist ceremony at home (if the temple was built at home). At the beginning of spring, festivals, pilgrims on Buddha Land such as Yen Tu, Huong Pagoda ... In Vietnam there are 14,775 pagodas, accounting for $36 \%$ of the total number of Vietnamese monuments. [11]. Many temples have been built with many historical and cultural values: One Pillar Pagoda, Kien So Pagoda, Ly Quoc Su Pagoda, Quan Su Pagoda, etc. When worshiping, the believers offer vegetarian aromas including incense, flowers fresh, tea, good fruit, lights, sputum (hemp), votive. It is estimated that the country burns 40 tons of votive every year. Hanoi alone accounts for one-tenth of that, or about 4 tons a year [6]. When carrying out recitation of the Buddha's recitation, the devotees dismiss all ordinary worries, focusing on the Buddha image, the prayer to make the mind not disturb. That is the practice of meditation, which shows the companion of Zen Pure. In the process of living, a part of believers occupying a small proportion of the people who attach importance to living the virtue, honesty, good living in daily life, worshiping the mother, respecting people, not doing things. evil, sinful. The practice of religious ritual is only a means of reaching the goal of enlightenment, so they do not suffer from superstitious activities such as divination, v.v... The second part, consisting of some of the lower classes, is not sufficiently comprehensive, often thanks to monks or lay people who are knowledgeable about Buddhist rituals, religious ceremony. They are often more focused on performing rituals, being easily manipulated into superstitious activities. Under conditions of integration, people's needs change, the activities of the temple also changes in the interpretation of some Buddhist laws, in the implementation of the requirements of the people as a star the term, absolve worship, pray, ... some of the temple to participate in economic activities: selling books publications serving utensils for performing ritual worship of believers,...

\subsubsection{Eating of Buddhist Law in Vietnam}

The five precepts are very flexible to suit the circumstances, the life, the faith.

Forbidden to kill, believers must respect the life of all living beings with the spirit of disobedience, selflessness, altruism of Buddhism - believers always forget themselves "save sentient beings." At present, laypeople practice vegetarian diets on certain days such as the full moon, the first day or the temple holiday. When they are sick, they can drink light medication or the believer can drink beer instead of alcohol at parties.

Believers make alms - sacrifice themselves for the happiness of others in a neutral way, not profitable. At present, Buddhist monks and nuns are active in responding to the movements of water and welfare, gratitude (building schools, houses of gratitude, supporting border guards, islands, visiting wounded soldiers and poor patients, ...); Helping difficult circumstances, "the leaves cover the torn", "love 
people as the body",...; To actively participate in production labor movements, participate in selfmanaged population quarters, contribute to maintaining political security and social order and safety; Interested in renovating pagodas, statues, casting bell. Particularly in Hanoi, among the 130 temples classified as cultural and historical relics (as of July 1994), more than $80 \%$ of the temples were repaired medium and large. At present, most temples are "electrified" as equipped with lights, even the speaker system is quite complete.

\subsection{International Significance from Research}

\subsubsection{Meaning in Moral Training}

The content of the "five precepts," "generosity," "purification of mind", ..., in essence are the moral principles required by social life in whatever Buddhist era Captured to regulate the behavior of believers. Therefore, in the process of forming human moral qualities, it is necessary to clearly see the positive and negative aspects of Buddhist ethics in order to exploit, inherit its positive elements, contribute to the building human morality conforms to the requirements of integration. Associate Professor Nguyen HuuVui, has commented: "... In any country, the great believers are the workers, so in their "believer piety", apart from the religious virtue there is an important part of the moral of the workers." $[8,157]$. In a market economy, there are many negative impacts on people and social relationships, on lifestyle, morals, etc. Then religious morality is consistent with the construction of a new world. The thought of the Buddha as the cause - results, karmic retribution, samsara, compassion - forgiveness, selflessness - good thinking, good direction, ... contribute to the formation of moral norms, adjust Moral behavior for the people. Since then, the way of life of goodness, selflessness, tolerance has become one of the manifestations of the civilized lifestyle of the whole world, making human relations more humane and humanitarian.

\subsubsection{Meaning in Building Up Human Personality}

In the world of cultural and spiritual life, the number of Buddhist followers, Buddhist festivals and Buddhist activities are becoming increasingly prominent in the social life, the number of Buddhist texts published ... increasingly increase. These phenomena have been constantly affecting people, and in fact have contributed to the creation of the human personality of Buddhism and that has influenced the development of human personality today.

\subsubsection{Significance in Developing Thinking}

Buddhist personallities oriented human beings always look at phenomena in causal relationships, dialectic. Thus, it contributes to the building of a natural and dynamic character for human beings against unpredictable changes of circumstances, disasters and hazards.

\section{CONClude}

Buddhism with unique humanity has brought a new nuance to the philosophy and treasure of human thought. The Buddhist doctrine, structured by the Four Noble Truths, presents a philosophical, logical view of human and human life. The views on "Five Aggregates," "Decalogue," "Karma," and "Karma," "Samsara," "Impermanence," and "Non-self." etchas a convincing interpretation of man and human life. The concept of liberation in Buddhist philosophy has shown very deep human nature. With the process of long-term admission and development in Vietnam, Buddhism has become a part of our country's culture and morals and has a great impact on our society. Today, in the context of integration, Buddhist life has deep international significance.

\section{REFERENCES}

[1] Nguyen Van Che, Basic Problems in Buddhist Studies. Buddhist Association of Vietnam published in 1976.

[2] Doan Chinh, liberation ideas in Indian philosophy. National Political Publishing House, Hanoi 1997.

[3] NhamKe Du (Editor), Religion dictionary. Shanghai Publishing Commune, 1985.

[4] KumuraTaiken (translated by ThichQuang Do), the Mahayana Buddhist thought. Buddhist Association of Ho Chi Minh City, 1997.

[5] Like Truthfulness, Buddhist doctrine. Vietnamese Buddhist Congregation, Board of Education monks published, 1993.

[6] Sports Culture Newspaper No. 12 dated 16/3/1998. 
Buddhist Personalities: From Doctrine to Practice in Vietnam during the Period of International Integration

[7] Sociological Review No. 4/1989.

[8] Institute of Religious Studies, Current Religious Issues. Social Sciences Publishing House, Hanoi, 1994.

[9] Institute of Philosophy, issues of Buddhism and history of thought in Vietnam. Vietnam Social Science Committee, Hanoi, 1986.

[10] https://vi.wikipedia.org/wiki/Số_lượng_Phật_tử_ở_các_nước]

[11] https://vi.wikipedia.org/wiki/Chùa_Việt_Nam].

Citation: Dr. Le Ngoc Thong. "Buddhist Personalities: From Doctrine to Practice in Vietnam during the Period of International Integration" International Journal of Humanities Social Sciences and Education (IJHSSE), vol 5, no. 8, 2018, pp. 24-31. doi: http://dx.doi.org/10. $20431 / 2349-0381.0508004$.

Copyright: (C) 2018 Authors. This is an open-access article distributed under the terms of the Creative Commons Attribution License, which permits unrestricted use, distribution, and reproduction in any medium, provided the original author and source are credited. 